\title{
The extant shore platform stromatolite (SPS) facies association: a glimpse into the Archean?
}

\author{
Alan Smith ${ }^{1,6}$, Andrew Cooper ${ }^{1,2}$, Saumitra Misra ${ }^{1}$, Vishal Bharuth ${ }^{3}$, Lisa Guastella ${ }^{4,6}$, and Riaan Botes ${ }^{5}$ \\ ${ }^{1}$ Discipline of Geology, School of Agriculture, Earth and Environmental Sciences, University of KwaZulu-Natal, \\ Westville 3630, South Africa \\ ${ }^{2}$ School of Environmental Science, University of Ulster, Coleraine, Northern Ireland, UK \\ ${ }^{3}$ Microscopy and Microanalysis Unit, University of KwaZulu Natal, Westville 3630, South Africa \\ ${ }^{4}$ Bayworld Centre for Research and Education (BCRE), Cape Town, South Africa \\ ${ }^{5}$ Geo-Dynamic Systems, P.O. Box 1283, Westville 3630, South Africa \\ ${ }^{6}$ Coast Busters Inc Research Group, 29 Brown's Grove, Sherwood, Durban 4091, South Africa
}

Correspondence: Alan Smith (asconsulting@telkomsa.net)

Received: 15 May 2017 - Discussion started: 27 June 2017

Revised: 12 February 2018 - Accepted: 23 February 2018 - Published: 13 April 2018

\begin{abstract}
Shore platform stromatolites (SPS) were first noted at Cape Morgan on the south-east African seaboard. Since then they have been found growing discontinuously in rocky peritidal zones along the entire southern African seaboard. They have also been found on the southwest Australian coast, at Giant's Causeway in Northern Ireland, and more recently at Harris on the Scottish Hebridean Atlantic coast. In this paper SPS occurrence and SPS potential as analogues for Precambrian fossil stromatolites, as well as potential stromatolite occurrences in shore platform regions on Mars, are assessed. Sub-horizontal surfaces promote stromatolite development, while tufa develops on cliffs and steep rocky surfaces. Tufa and stromatolites are end members of a spectrum dictated by coastal topography. Extant SPS occur on well indurated shore platforms in high wave energy settings, often around or near headlands. They can be associated with boulder beaches, boulder ridges, storm swash terraces, coastal dunes, and peat bogs. In contrast to other extant stromatolites, SPS are produced primarily by mineral precipitation, although minor trapping and binding stromatolites do occur. From a geological perspective, SPS develop in mildly transgressive siliciclastic settings in various climatic and tidal regimes. We suggest that SPS could be preserved in the geological record as micritic lenses on palaeo-shore platform surfaces. SPS share many features with Precambrian stromatolites and are a valid modern analogue despite the widely different atmospheric and oceanic conditions of
\end{abstract}

the Archean. We suggest that terraces associated with former oceanic or lacustrine flooding surfaces on Mars are potential targets in the search for palaeo-SPS on Mars.

\section{Introduction}

The oldest known stromatolites include those of the Isua Group (3.7 Ga), Greenland (Nutman et al., 2016); the Strelley Pool occurrence $(3.43 \mathrm{Ga})$, Australia (Allwood et al., 2006); the Barberton Mountain Land (3.22 Ga), South Africa (Gamper et al., 2011); and the Pongola Group (2.9 Ga), South Africa (Mason and von Bruun, 1977; Bolhar et al., 2015). Comparison of the environment in which extant and sub-fossil stromatolites occur with ancient examples may advance our knowledge concerning the conditions under which life developed and in what environment it began. Stromatolite-building organisms probably dominated the Earth during the Archean and Proterozoic eons, but under contemporary conditions only thrive in extreme environments that limit metazoan competition. Such environments include geothermal springs (Jones et al., 2000; Berelson et al., 2011), peritidal marine environments (Logan et al., 1964; Reid et al., 2000; Smith and Uken, 2003; Smith et al., 2005, 2011; Perissinotto et al., 2014; Rishworth et al 2016; Edwards et al., 2017), and salt lakes (Martin and Wilczewski, 1972). Prokaryotes are also recorded from the Earth's upper 


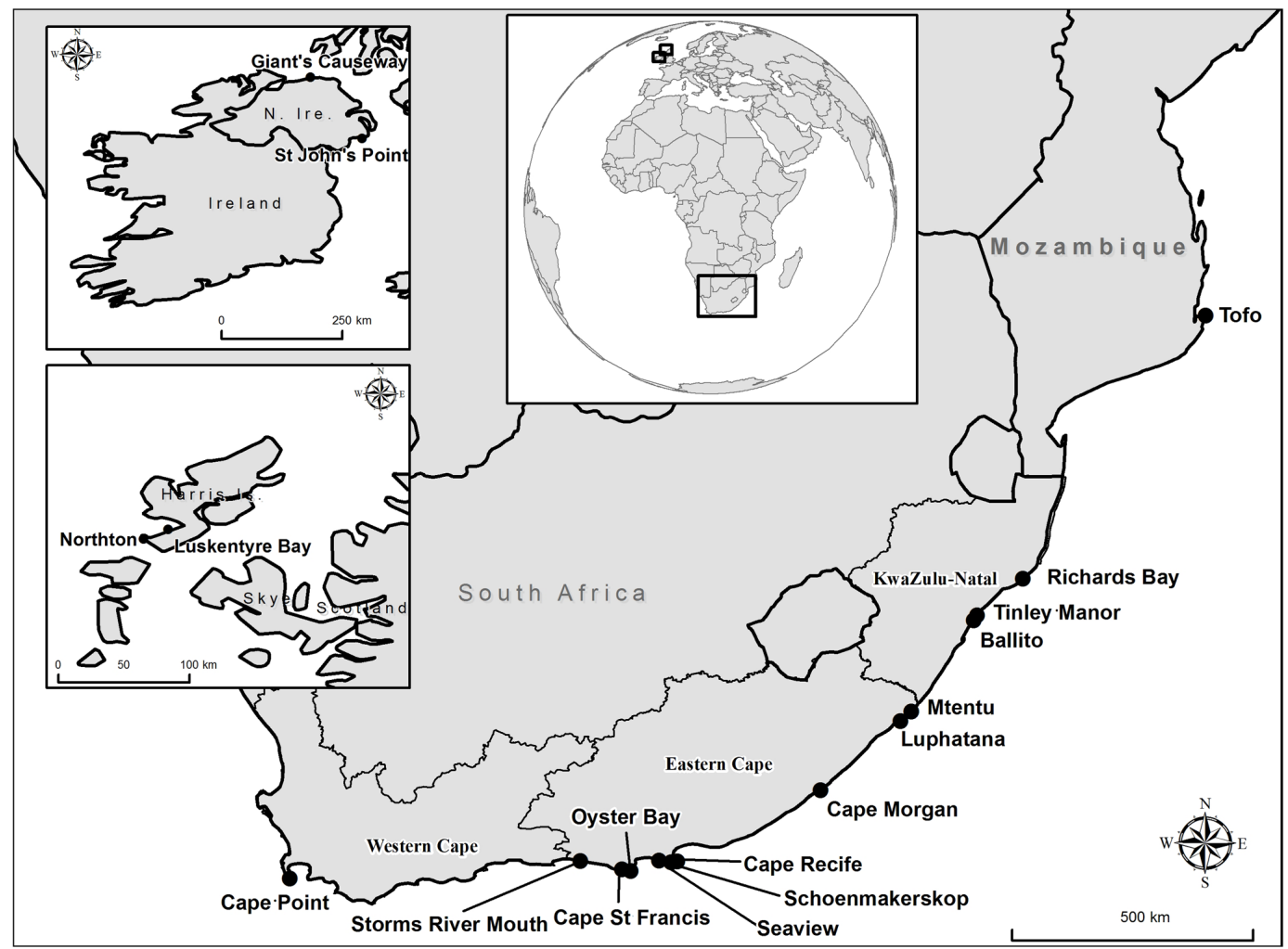

Figure 1. Location of SPS sites on the eastern seaboard of southern Africa, Northern Ireland and the Scottish Hebrides.

crust to depths of (at least) $7 \mathrm{~km}$ (Sankaran, 1997) and within the troposphere (DeLeon-Rodriguez et al., 2012).

Stromatolites are biosedimentary structures produced by sediment trapping and binding and/or mineral precipitation as a result of the growth and metabolic activity of a microbial community (Awramik and Marguilis, 1976; Burne and Moore, 1987). The best known extant stromatolite models are based on the trapped and bound stromatolites of Shark Bay, Western Australia and several sites in the Caribbean (Logan et al., 1964; Reid and Browne, 1991). Precambrian stromatolites, in contrast, are of the mineral precipitation variety (Awramik and Grey, 2005; Reid et al., 2011; Smith et al., 2011; Perissinotto et al., 2014; Rishworth et al., 2016; Edwards et al., 2017) and offer a plausible Precambrian stromatolite analog, which deserves scrutiny.

Cape Morgan (Fig. 1) in the Eastern Cape province, South Africa, was the first location where SPS were found. SPS form on shore platforms within the peritidal zone where suitable (carbonate-rich) terrestrial runoff is present (Smith et al., 2011; Perissinotto et al., 2014; Rishworth et al., 2016). These supratidal/ high intertidal zones experience extreme environmental changes, which partially exclude metazoans (Perissinotto et al., 2014; Rishworth et al., 2016) and enable prokaryotes to dominate. The Cape Morgan locality was discovered by Mountain (1937), although its significance was only realised much later (Smith and Uken, 2003). Smith et al. (2011) proposed the extant Cape Morgan (Fig. 1) stromatolites as a partial analogue for the $3.43 \mathrm{Ga}$ stromatolites from Strelley Pool Australia. Smith et al. (2011) furthermore documented extant and subfossil SPS from Cape Morgan and indicated that they were found in patches from Tofo (Mozambique) to Port Elizabeth (Eastern Cape, South Africa)(Fig. 1). Since then colonies have been found in Northern Ireland (Cooper et al., 2013), additional localities in the Eastern Cape province have been documented, (Perissinotto et al, 2014; Rishworth et al., 2016; Edwards et al., 2017),and further colonies elsewhere in southern Africa have been uncovered (Fig. 1). More recently, new SPS discoveries have also been made on the west coast of Harris, in the Scottish Hebrides.

\section{Methodology}

This work is heavily reliant on fieldwork which has taken advantage of many serendipitous trips. No attempt has been made to institute a scientific survey due to the geographical distances involved and limited manpower. Stromatolite (SPS in this paper) morphology, microstructure, and ecology is discussed in detail elsewhere (Smith et al., 2011; Perissinotto et al., 2014; Rishworth et al., 2016, 2017; Edwards et al., 2017). New localities are discussed and compared with known; such review is required to establish similarities and differences. This paper will consequently focus 
Table 1. Location, context and stromatolite type of SPS localities (Y: yes; N: no; n/r: no record).

\begin{tabular}{|c|c|c|c|c|c|c|}
\hline Location & Coordinates & $\begin{array}{l}\text { Shore } \\
\text { platform }\end{array}$ & Cliff & $\begin{array}{l}\text { Trapped } \\
\text { and bound }\end{array}$ & $\begin{array}{l}\text { Mineral } \\
\text { precipitation }\end{array}$ & Tufa \\
\hline Cape Point, SA & $\begin{array}{l}34^{\circ} 20^{\prime} 48.42^{\prime \prime} \mathrm{S} ; \\
18^{\circ} 27^{\prime} 48.16^{\prime \prime} \mathrm{E}\end{array}$ & $\mathrm{Y}$ & $\mathrm{Y}$ & & & $\mathrm{Y}$ \\
\hline${ }^{1}$ Storms River & $\begin{array}{l}34^{\circ} 10^{\prime} 34^{\prime \prime} \mathrm{S} \\
24^{\circ} 39^{\prime} 46^{\prime \prime} \mathrm{E}\end{array}$ & $\mathrm{Y}$ & $\mathrm{n} / \mathrm{r}$ & $\mathrm{N}$ & $\mathrm{Y}$ & $\mathrm{n} / \mathrm{r}$ \\
\hline${ }^{1}$ Oyster Bay & $\begin{array}{l}34^{\circ} 11^{\prime} 25.07^{\prime \prime} \mathrm{S} \\
24^{\circ} 41^{\prime} 43.76^{\prime \prime} \mathrm{E}\end{array}$ & $\mathrm{Y}$ & & $\mathrm{N}$ & $\mathrm{Y}$ & $\mathrm{n} / \mathrm{r}$ \\
\hline${ }^{1}$ Cape St Francis & $\begin{array}{l}34^{\circ} 12^{\prime} 49^{\prime \prime} \mathrm{S} \\
24^{\circ} 50^{\prime} 04^{\prime} \mathrm{E}\end{array}$ & $\mathrm{Y}$ & $\mathrm{N}$ & $\mathrm{N}$ & $\mathrm{Y}$ & $\mathrm{n} / \mathrm{r}$ \\
\hline${ }^{1}$ Seaview & $\begin{array}{l}34^{\circ} \_01^{\prime} 03.16^{\prime \prime} \mathrm{S} ; \\
25^{\circ} \_21^{\prime} 56.48^{\prime \prime} \mathrm{E}\end{array}$ & $\mathrm{Y}$ & $\mathrm{N}$ & $\mathrm{N}$ & $\mathrm{Y}$ & $\mathrm{n} / \mathrm{r}$ \\
\hline${ }^{1}$ Skoenmakerskop & $\begin{array}{l}34^{\circ} \_02^{\prime} 28.23^{\prime \prime} \mathrm{S} \\
25^{\circ} \_32^{\prime} 18.60^{\prime \prime} \mathrm{E}\end{array}$ & $\mathrm{Y}$ & $\mathrm{N}$ & $\mathrm{Y}$ & $\mathrm{Y}$ & $\mathrm{n} / \mathrm{r}$ \\
\hline${ }^{1}$ Cape Recife & $\begin{array}{l}34^{\circ} \_02^{\prime} 42.13^{\prime \prime} \mathrm{S} \\
25^{\circ} \_34^{\prime} 07.50^{\prime \prime} \mathrm{E}\end{array}$ & $\mathrm{Y}$ & $\mathrm{N}$ & $\mathrm{N}$ & $\mathrm{Y}$ & $\mathrm{n} / \mathrm{r}$ \\
\hline${ }^{2}$ Cape Morgan & $\begin{array}{l}32^{\circ} 41^{\prime} 36^{\prime \prime} \mathrm{S} \\
28^{\circ} 22^{\prime} 27^{\prime \prime} \mathrm{E}\end{array}$ & $\mathrm{Y}$ & Minor & $\mathrm{Y}$ & $\mathrm{Y}$ & $\mathrm{Y}$ \\
\hline Luphatana & $\begin{array}{l}31^{\circ} 25^{\prime} 10^{\prime \prime} \mathrm{S} \\
29^{\circ} 51^{\prime} 30^{\prime \prime} \mathrm{E}\end{array}$ & $\mathrm{Y}$ & $\mathrm{N}$ & $\mathrm{N}$ & $\mathrm{Y}$ & $\mathrm{N}$ \\
\hline Mtentu & $\begin{array}{l}31^{\circ} 14^{\prime} 30^{\prime \prime} \mathrm{S} \\
31^{\circ} 03^{\prime} 22^{\prime \prime} \mathrm{E}\end{array}$ & $\mathrm{Y}$ & $\mathrm{N}$ & $\mathrm{N}$ & $\mathrm{Y}$ & $\mathrm{N}$ \\
\hline Port Edward & $\begin{array}{l}31^{\circ} 02^{\prime} 55.26^{\prime \prime} \mathrm{S} \\
30^{\circ} 13 \\
{ }^{\prime} 47.79^{\prime \prime} \mathrm{E}\end{array}$ & $\mathrm{Y}$ & $\mathrm{N}$ & $\mathrm{N}$ & $\mathrm{Y}$ & $\mathrm{N}$ \\
\hline Ballito & $\begin{array}{l}29^{\circ} 32^{\prime} 15^{\prime \prime} \mathrm{S} \\
31^{\circ} 13^{\prime} 20^{\prime \prime} \mathrm{E}\end{array}$ & $\mathrm{Y}$ & Minor & $\mathrm{N}$ & $\mathrm{Y}$ & $\mathrm{N}$ \\
\hline Tinley Manor & $29^{\circ} 26^{\prime} 43.98^{\prime \prime} \mathrm{S}$ & Y & Minor & $\mathrm{N}$ & $\mathrm{Y}$ & Minor \\
\hline Richards Bay & $\begin{array}{l}31^{\circ} 17^{\prime} 26.99^{\prime \prime} \mathrm{E} \\
28^{\circ} 46^{\prime} 15.20^{\prime \prime} \mathrm{S}\end{array}$ & $\mathrm{X}$ & $\mathrm{Y}$ & $\mathrm{N}$ & $\mathrm{Y}$ & $\mathrm{Y}$ \\
\hline Tofo, Mozambique & $\begin{array}{l}32^{\circ} 08^{\prime} 00.32^{\prime \prime} \mathrm{E} \\
23^{\circ} 41^{\prime} 26^{\prime \prime} \mathrm{S} \\
35^{\circ} 33^{\prime} 04^{\prime \prime} \mathrm{E}\end{array}$ & $\mathrm{Y}$ & $\mathrm{Y}$ & $\mathrm{N}$ & $\mathrm{Y}$ & $\mathrm{N}$ \\
\hline${ }^{3}$ Giant's Causeway, N. Ireland, UK & See reference & $\mathrm{Y}$ & $\mathrm{Y}$ & $\mathrm{N}$ & $\mathrm{Y}$ & $\mathrm{N}$ \\
\hline St John’s Point, N. Ireland, UK & $54^{\circ} 13^{\prime} 31.23^{\prime \prime} \mathrm{N}$ & $\mathrm{Y}$ & $\mathrm{Y}$ & $\mathrm{N}$ & $\mathrm{Y}$ & $\mathrm{N}$ \\
\hline Luskentyre Bay (S), Harris, UK & $\begin{array}{l}5^{\circ} 39^{\prime} 32.69^{\prime \prime} \mathrm{W} \\
57^{\circ} 52^{\prime} 08.73^{\prime \prime} \mathrm{N}\end{array}$ & $\mathrm{Y}$ & $\mathrm{Y}$ & $\mathrm{N}$ & $\mathrm{Y}$ & $\mathrm{Y}$ \\
\hline Luskentyre Bay (N), Harris, UK & $\begin{array}{l}6^{\circ} 57^{\prime} 42.01^{\prime \prime} \mathrm{W} \\
57^{\circ} 52^{\prime} 17.65^{\prime \prime} \mathrm{N}\end{array}$ & $\mathrm{Y}$ & $\mathrm{N}$ & $\mathrm{Y}$ & $\mathrm{Y}$ & $\mathrm{N}$ \\
\hline Northton, Harris, UK & $\begin{array}{l}6^{\circ} 54^{\prime} 28.52^{\prime \prime} \mathrm{W} \\
57^{\circ} 48^{\prime} 09.56^{\prime \prime} \mathrm{N}\end{array}$ & $\mathrm{N}$ & $\mathrm{Y}$ & $\mathrm{N}$ & $\mathrm{Y}$ & $\mathrm{Y}$ \\
\hline & $7^{\circ} 04^{\prime} 57.52^{\prime \prime} \mathrm{W}$ & & & & & \\
\hline${ }^{4}$ Kuwait Bay, Kuwait & See reference & $\mathrm{Y}$ & $\mathrm{N}$ & $\mathrm{N}$ & $\mathrm{Y}$ & $\mathrm{N}$ \\
\hline${ }^{5}$ N. Sea, Netherlands & See reference & $\mathrm{N}$ & $\mathrm{N}$ & $\mathrm{n} / \mathrm{r}$ & NA & $\mathrm{N}$ \\
\hline${ }^{6} \mathrm{SW}$ Australia & See reference & $\mathrm{Y}$ & $\mathrm{Y}$ & $\mathrm{N}$ & $\mathrm{Y}$ & $\mathrm{Y}$ \\
\hline Monkey Mia, W. Australia & Not known & Y & $\mathrm{N}$ & $\mathrm{N}$ & $\mathrm{Y}$ & $\mathrm{N}$ \\
\hline
\end{tabular}

$\mathrm{NA}=$ this data is not available
${ }^{1}$ Perissinotto et al. (2014), ${ }^{2}$ Smith and Uken (2003), ${ }^{3}$ Cooper et al. (2013), ${ }^{4}$ Alshuaibi et al. (2015), ${ }^{5}$ Kremer et al. (2008), ${ }^{6}$ Forbes et al. (2010). 


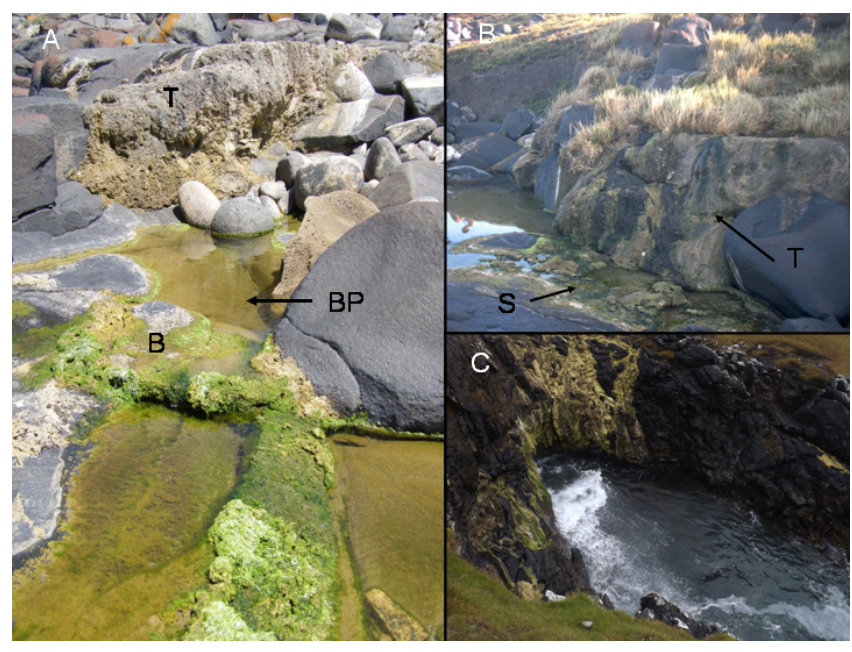

Figure 2. (a) Shore platform showing a low tufa curtain (T), barrage (B), and pool (BP). (b) Higher tufa curtain (T) forming on a cliff at the back of the dolerite shore platform with stromatolites (S) at its toe (a and $\mathbf{b}$ from Cape Morgan), and (c) Tufa curtain from Northton, Harris, UK. Here there is no shore platform.

on the synthesis of a facies association using tabulated geomorphological, lithological, oceanographic, and climatological elements. This is a relatively new branch of stromatolite science and is heavily reliant on description and comparisons.

We document all known SPS localities (Table 1) with the aim of distilling of a generalised global SPS facies association. To this end we also describe several new SPS localities on the southern African eastern seaboard and on the Atlantic side of Harris Island in the Scottish Hebrides, UK. We then compile and review the physical, oceanographic, climatological, lithological, and geomorphological settings in which extant SPS are forming in the Scottish Hebrides, the northeast coast of Northern Ireland and the southern African seaboard. All known SPS location coordinates and source data are given in Table 1. On the basis of this review, we present a facies association model for SPS.

We then compare the SPS facies association to extant stromatolites from contrasting peritidal environments in Hamelin Pool, Western Australia (Logan et al., 1964), Kuwait (Alshuaibi et al 2015), the Bahamas (Reid et al., 2000), and the Dutch North Sea (Kremer et al., 2008). Further, on the basis of this comparison, extant SPS are assessed as potential analogues for Precambrian stromatolites. We also comment briefly on potential target location regarding the search for SPS on Mars.

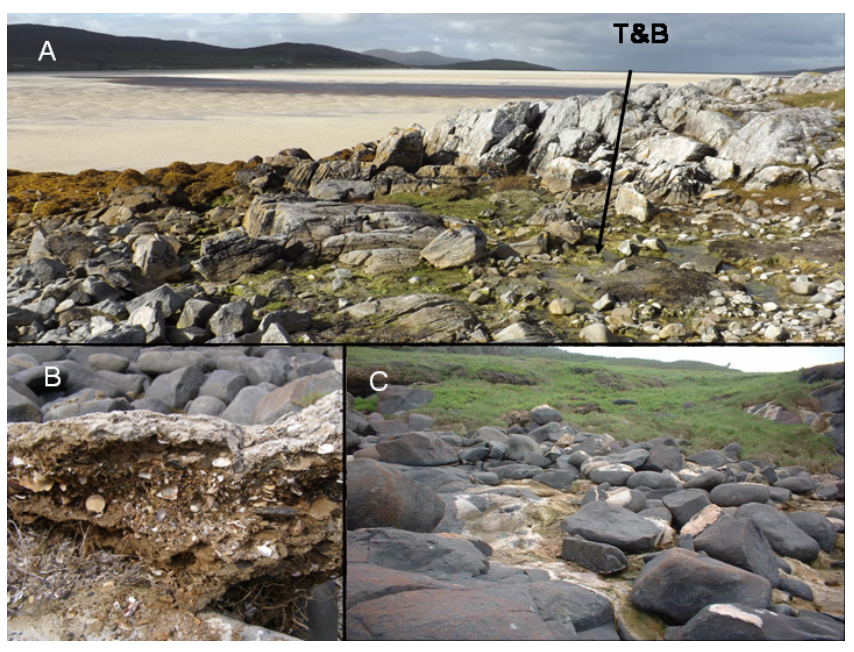

Figure 3. (a) Trapped and bound stromatolites forming on a stromatolite apron, located on the Luskentyre Bay shore platform, Harris, UK. The stromatolite is growing around cobbles swept onto the apron by inflowing water. (b) Trapped and bound stromatolites developed on a cobble beach adjacent to a shore platform. Note the shell debris which has been bound into the Cape Morgan stromatolite. (c) Dolerite boulders quarried from the shore platforms and bound by stromatolite growth. (b) and (c) are reproduced from Smith et al. (2005, 2011).

\section{Results}

\subsection{SPS distribution}

Extant shore platform stromatolites (SPS) occur discontinuously along a $2300 \mathrm{~km}$ stretch of the southern African eastern seaboard (Fig. 1; Table 1), in addition to locations in Western Australia (Forbes et al., 2010), and Giant's Causeway, Northern Ireland (Cooper et al., 2013). All known SPS occurrences are based on opportunistic observation as no systematic survey of their location has yet been made. SPS often occur in association with tufa but the proportions vary with the coastal geomorphology. All SPS colonies are fed by spring water emanating from the terrestrial hinterland (Smith et al., 2011; Perissinotto et al., 2014; Edwards et al., 2017). If the coastline is cliffed or dominated by high-angle surfaces, tufa dominates (Fig. 2a, b), whereas SPS typically occur within rock pools on competent sub-horizontal shore platforms (Fig. 2a). In many instances there is a clear spatial gradation from tufa to stromatolites (Fig. 2a and b). Most SPS develop directly on the shore platform but the trapped and bound (Fig. 3) variety develops adjacent to, and in channels cut into, the shore platform.

\subsection{Trapped and bound SPS}

Trapped and bound stromatolites are relatively rare, having only been observed at Cape Morgan (Smith et al., 2011; Fig. 3), Seaview Skoenmakerskop (South Africa: see Ed- 
Table 2. Lithological features of shore platforms (N/R: no record).

\begin{tabular}{|c|c|c|c|c|c|}
\hline Location & Lithology & Attitude & $\begin{array}{l}\text { Boulders } \\
\text { present }\end{array}$ & Age & Bedrock status \\
\hline Cape Point, SA & Sandstone (Nardou) & Folded & Boulder beach & Ordovician & very indurated \\
\hline Storms River & Sandstone (Nardou) & Folded & Boulder ridge & Ordovician & very indurated \\
\hline Oyster Bay & S/Stone (Nardou) & $\mathrm{n} / \mathrm{r}$ & $\mathrm{n} / \mathrm{r}$ & Ordovician & very indurated \\
\hline St Francis & S/Stone (Nardou) & & $\mathrm{n} / \mathrm{r}$ & Ordovician & very indurated \\
\hline Seaview & ${ }^{1}$ Quartzites, grits and phyllites & Deformed & Boulders in pools & Precambrian & very indurated \\
\hline Skoenmakerskop & ${ }^{1}$ Metaseds (Sardinia Bay Fm) & Deformed & $\mathrm{n} / \mathrm{r}$ & Ordovician & very indurated \\
\hline Cape Recife & S/Stone (Nardou) & Deformed & $\mathrm{n} / \mathrm{r}$ & Ordovician & very indurated \\
\hline 2 Cape Morgan & Dolerite & Sill & Boulder ridge & Jurassic & Fresh \\
\hline Luphatana & S/Stone (Msikaba) & Horizontally bedded & Boulder ridge & L Devonian & very indurated \\
\hline Mtentu & S/Stone (Msikaba) & Horizontally bedded & Boulder ridge & L Devonian & very indurated \\
\hline Port Edward & Granite & Deformed & Boulder ridge & $1.1 \mathrm{Ga}$ & Fresh \\
\hline Ballito & Dolerite & Sill & Storm beach & Jurassic & Fresh \\
\hline Tinley Manor & Dolerite & Sill & Storm beach & Jurassic & Fresh \\
\hline Richards Bay & $\begin{array}{l}\text { Pt Durnford Fm } \\
\text { muds, silts, F/sst }\end{array}$ & Sea cliff & Storm beach & Pleistocene & Semi-consolidated \\
\hline $\begin{array}{l}\text { Tofo, Mozam- } \\
\text { bique }\end{array}$ & Tufa (no base seen) & Massive & Storm beach & Pleistocene & Tufa \\
\hline $\begin{array}{l}{ }^{3} \text { Giants Cause- } \\
\text { way, N. Ireland }\end{array}$ & Basalt & Columnar basalt & Storm beach & Cretaceous & Fresh \\
\hline $\begin{array}{l}\text { St John's Point, } \\
\text { N. Ireland }\end{array}$ & Limestone & $\mathrm{n} / \mathrm{r}$ & Storm beach & Lower Carboniferous & Fresh \\
\hline $\begin{array}{l}\text { Luskentyre Bay } \\
\text { (North), Harris } \\
\text { Island, UK }\end{array}$ & Granitic & Deformed & Storm beach & Proterozoic-Archean & Fresh \\
\hline $\begin{array}{l}\text { Luskentyre Bay } \\
\text { (South), Harris } \\
\text { Island, UK }\end{array}$ & Granitic & Deformed & Storm beach & Proterozoic-Archean & Fresh \\
\hline $\begin{array}{l}\text { Northton, Har- } \\
\text { ris Island, UK }\end{array}$ & Granitic & Sea cliff & $\mathrm{N}$ & Archean & Fresh \\
\hline $\begin{array}{l}{ }^{4} \text { Kuwait Bay, } \\
\text { Kuwait }\end{array}$ & Beach rock & Bedded & Not present & Late Quaternary & Fresh \\
\hline${ }^{5}$ SW.Australia & Limestone/granite & $\mathrm{n} / \mathrm{r}$ & Storm beach & $\begin{array}{l}\text { Pleistocene limestone/ } \\
\text { granite (540-780 Ma) }\end{array}$ & Fresh \\
\hline $\begin{array}{l}\text { Monkey Mia, } \\
\text { W. Australia }\end{array}$ & Not known & $\mathrm{n} / \mathrm{r}$ & Not present & $\mathrm{n} / \mathrm{r}$ & Fresh \\
\hline
\end{tabular}

${ }^{1}$ Perissinotto et al. (2014), ${ }^{2}$ Smith and Uken (2003), ${ }^{3}$ Cooper et al. (2013), ${ }^{4}$ Alshuaibi et al. (2015), ${ }^{5}$ Forbes et al. (2010).

wards et al., 2017), and the north coast of Luskentyre Bay (Harris, UK). This stromatolite type appears to be restricted to clastic environments associated with the shore platform system and are therefore still termed SPS. Trapped and bound stromatolites are found growing on cemented beach gravel in breaks and gullies in the shore platform and beaches adjacent to the shore platform. The size of beach grain involved varies from fine sand to boulders. A storm beach deposit (6-10 cm thick) bound between two mineralised laminar stromatolites has been observed (Fig. 3b) (Smith et al., 2011). In addition, within a depression in the Cape Morgan shore platform, a headland conglomerate formed by stromatolite cementation of dolerite boulders is present (Smith et al., 2005); some of these boulders have been disaggregated and re-cemented into the conglomerate (Fig. 3c). Trapped and bound stromatolites are also known to be associated with strong terrestrial runoff.

\subsection{Mineral precipitated stromatolites}

Mineral precipitated stromatolites (which generally lack trapped and bound material) dominate the SPS facies association (Table 2; Fig. 1). SPS grow on shore platforms, within chemically - or mechanically - produced pools and barrage pools (see: Forbes et al., 2010), constructed by stromatolite growth and the inclined apron terrace slopes that connect them (Fig. 4b) (Campbell et al., 2015). The water in these shore platform pools is known to vary from fresh to hypersaline (Smith et al., 2011; Perissinotto et al., 2014) depending on immediate wave and weather conditions. Elevated water temperatures, as much as $10^{\circ} \mathrm{C}$ above ambient environmental, at Cape Morgan, Luphatana and Richards Bay suggest inputs from warm thermal spring activity (Smith et al., 2011). These warm waters often occur at the base of pools, separated from the overlying water by a thermocline; in such cases, SPS growth is absent below the thermocline 


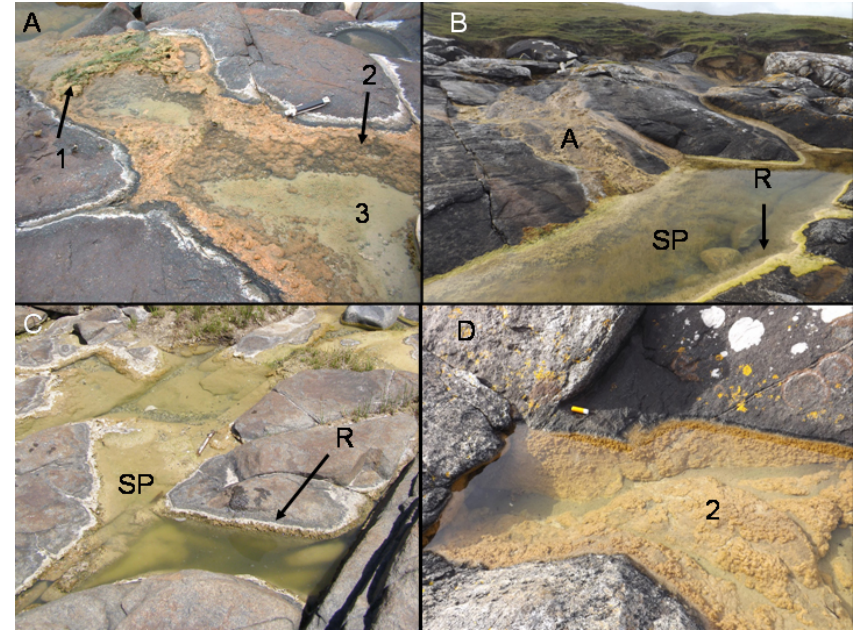

Figure 4. SPS mineral precipitated stromatolites. (a) Stromatolite pool showing: pustular (1), laminar and columnar (2), and colloform (3) stromatolite types from Cape Morgan, South Africa. (b) Stromatolite pool (SP), stromatolite apron (A), and stromatolite rim (R). (c) Joint controlled stromatolite pool (SP) and stromatolites, and a stromatolite rim (R). Both (b) and (c) are from Luskentyre Bay, Harris, UK. (d) Stromatolite pool from Mtentu, South Africa.

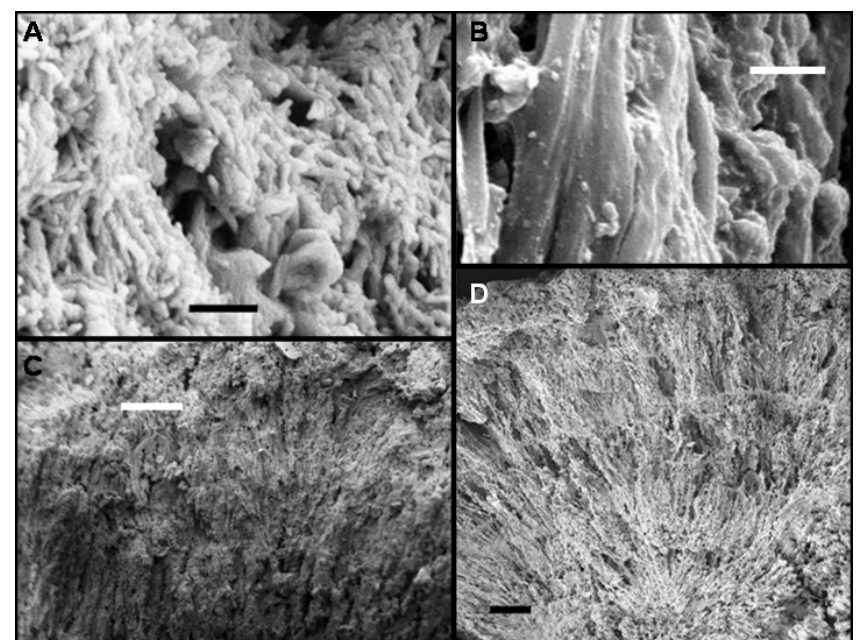

Figure 5. (a) High-magnification SEM image of stromatolite from Tofo (scale bar is $1 \mu \mathrm{m}$ ); (b) growing cyanobacteria filaments from Morgans Bay microbialite (scale bar is $10 \mu \mathrm{m}$ ); (c) calcified cyanobacteria filaments from Ballito (scale bar is $40 \mu \mathrm{m}$ ) and (d) domical calcified stromatolite from Morgans Bay (scale bar is $400 \mu \mathrm{m})$.

(Smith and Uken, 2003). At Cape Morgan and Tinley Manor, stromatolite colonies are clearly being fed by springs that emanate from a storm swash terrace, whereas at Luskentyre Bay, the colonies are fed from seeps flowing out of a peat bog (Fig. 6d). Water ponding within suitable topography on shore platform surfaces provides accommodation space for growing SPS. SPS are variously present as thin crusts (1$30 \mathrm{~cm}$ thick), barrage deposits (Perissinotto et al., 2014), low mounds ( $>20 \mathrm{~cm}$ high), and as oncoid-like cobble and boulder coatings (Edwards et al., 2017). These cobbles and boulders are probably the grinders involved in pothole production.

SPS growth zones are related to water physicochemistry, calcification, and limited to salinity values of $<20$ psu (generally 2-10 psu) (Smith et al., 2011; Perissinotto et al., 2014; Edwards et al., 2017). In areas where groundwater discharge is very strong coralline red algae may alternate with tufa growth in the lower part of cliffs reaching down into the lower intertidal zone. SPS may therefore cease growing, desiccate, and suffer rain dissolution, and then regrow forming erosion surfaces. Growth cessation may be due to "self" blocking of the water conduit by stromatolite growth and carbonate precipitation, wave erosion, or drought conditions interrupting groundwater inflow.

Three depth-controlled, stromatolite morphologies have been reported from pools (Fig. 4a) (Smith et al., 2011; Perissinotto et al., 2014; Rishworth et al., 2016; Edwards et al., 2017). Partially emergent pustular stromatolites occur in the subareal wet area around pools and seeps (Fig. 4). This morphology occurs as mounds up to a few centimetres above pool rims and in very shallow water. At some localities (e.g. Luphatana and Mtentu: Fig. 1) the pustular stromatolite variety is not present. In these cases water inflow is via joint planes directly into the pools. Pustular stromatolite morphology is often a link morphology between stromatolites and tufa (Fig. 4a). Laminar and columnar stromatolites $(1-10 \mathrm{~cm}$ high) occur in shallow water (Fig. 4a). This stromatolite morphology forms a pool rim at, and just below, the water surface (Smith et al., 2011; Edwards et al., 2017). Laminar stromatolite morphology is particularly common in the windshadow margins of pools, whereas in deeper pools $(20-30 \mathrm{~cm}$ depth) only the colloform stromatolite morphology is present (Fig. 4a). SPS are highly colourful during bloom (Fig. 3), but become white on desiccation to a micrite crust.

The mineral precipitated SPS generally lack the particles that are present within the trapped and bound SPS (Fig. 5). The mineral precipitated SPS variation are characterised by a laminae comprising radiating cyanobacterial filaments, alternating with thinner concentric lamina (Fig. 5c, d). Radial SPS lamination is on a centimetre scale, whereas the concentric lamination is much thinner (Fig. 5b). Mineral precipitated stromatolites may contain trapped and bound material but this is rare. This suggests that the SPS trapped and bound and mineral precipitated stromatolites are end members of a continuous spectrum.

\subsection{Tufa}

Tufa waterfalls (see Perissinotto et al., 2014); varying from a few centimetres to several metres high, often coat cliffs and steep rock surfaces (Table 1; Fig. 3a, b). Tufa dominates 


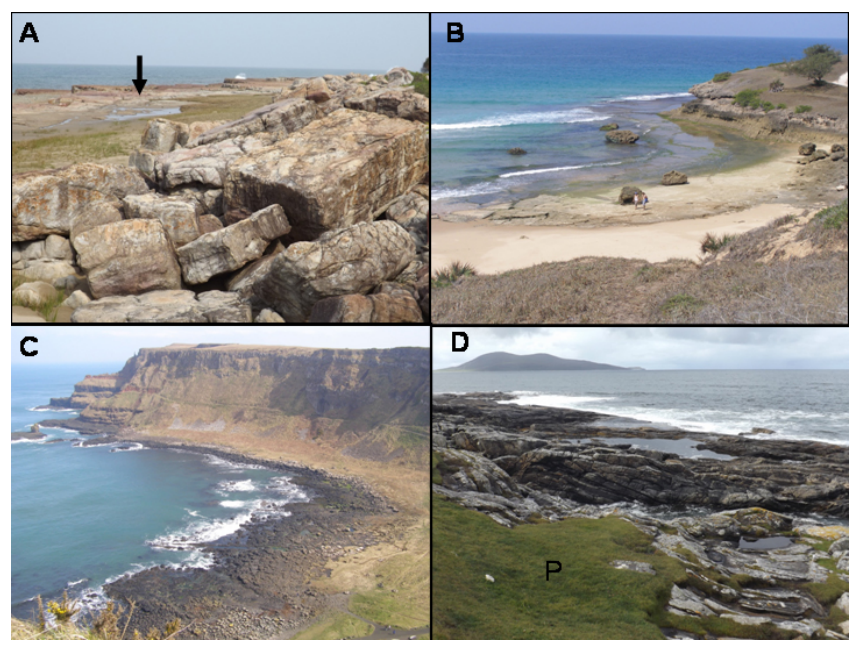

Figure 6. (a) Sandstone shore platform and boulder ridge at Luphatana, South Africa. Stromatolites are growing in the pool (see black arrow); $80 \mathrm{t}$ boulders are present in the boulder ridge showing the contrasting shore platform environmental extremes. (b) Tofo, Mozambique, tufa shore platform with scattered large boulders. (c) Giant's Causeway basalt shore platform and cliffs. (d) Lewisian gneiss shore platform at Luskentyre Bay, Harris, UK - Note the peat marsh $(\mathrm{P})$.

on coastlines characterised by sea cliffs (Table 2). At Cape Morgan an inter layering of tufa and coralline red algae was noted in the lower part of the intertidal zone at a locality characterised by a strong water inflow. If only cliffs are present (and no shore platform) only tufa is present. Tufa waterfalls are also often connected to SPS pools, either directly at the tufa toe or via connecting apron terraces.

\section{Geomorphology and geology of SPS settings}

All locations discussed are open coast except for Luskentyre Bay and Kuwait Bay (Table 2). The geomorphology of each shore platform is controlled by lithology, jointing, and bedding style. Shore platforms comprised a variety of competent lithologies (Table 2). Shore platforms vary from 5-60 m wide and are generally backed by a boulder beach or boulder ridge (Fig. 6). The boulder ridges contain angular blocks or megaclasts (up to $80 \mathrm{t}$ ), as opposed to the smaller ( $>50 \mathrm{~cm}$ diameter) rounded boulders found in boulder beaches and gullies in, and adjacent to, the shore platform (Table 2).

Where the coast comprises incompetent lithologies no shore platforms can form. Competent sandstones form wide shore platforms (Fig. 6; Table 2). The SPS bearing shore platforms at Mtentu and Luphatana (Fig. 6c; Table 2) are formed in well-indurated Lower Devonian Msikaba Formation sandstone. These are the widest at up to $60 \mathrm{~m}$ wide. The Msikaba Formation is well-bedded (more-or-less horizontal) and vertically jointed. The shore platform has been formed by wave quarrying of large blocks, which break along bedding

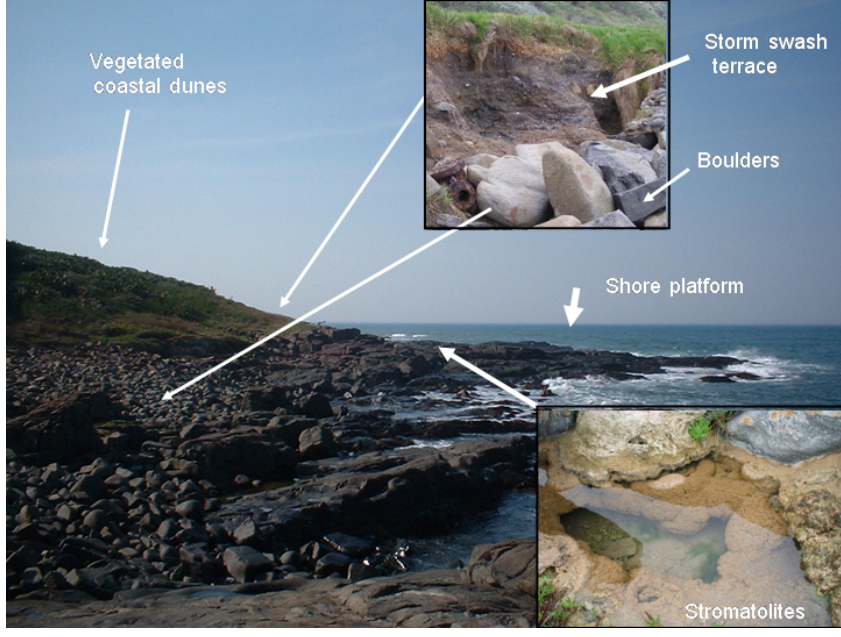

Figure 7. SPS facies association model based around the Cape Morgan SPS context.

and joint planes. The eroded boulders have accumulated in a boulder ridge at the rear of the platform (Fig. 6a).

At Cape Point SPS occurrences are rare but massive tufa deposits are present inland. Tufa is the main lithological component at Tofo, in comparison, and the shore platform has been excavated into this lithology (Fig. 6b), with thin (1$2 \mathrm{~cm}$ thick) sub-fossil stromatolites interbedded (Table 2). Sub-fossil mineral precipitated stromatolites are also found as upper intertidal and supra tidal active pothole linings. No growing tufa or stromatolites were observed, but the presence of SPS in potholes within an active shore platform indicates them to be recent. It is possible that this tufa deposit is related to a lower sea level stillstand and has been reworked into a shore platform where SPS has developed at a later stage.

Dolerite sill shore platforms are present at Tinley Manor, Ballito, and Cape Morgan (Fig. 1); the latter (Fig. 7) being the best example (Table 2). The dolerite is strongly jointed and forms a rugged shore platform, which tends to undulate and shows minor sea cliffs and pools. The sea cliffs are produced by wave bore quarrying of blocks along joint surfaces. Pools, in comparison, are formed by mechanical joint widening, pot holing, and chemical weathering, while barrage pools are impounded by stromatolite growth (Fig. 4).

At Port Edward (Fig. 1) granite forms a poorly developed shore platform littered with megaclasts. Minor SPS and tufa were noted near the landward shore platform boundary. The Luskentyre Bay, Harris Island, Scottish Hebrides (Fig. 1) granitic shore platform is backed by an extensive but thin $( \pm 30 \mathrm{~cm})$ peat bog. Seaward of this shore platform is a very extensive intertidal fine-grained low-end macrotidal flat (Fig. 6).

At Richards Bay (Fig. 1) the south-east African coastline is marked by the semi-indurated Pleistocene Port Durnford beds (Fig. 1), which comprise incompetent muds, silts and fine sands. The shore platform is poorly developed and 
Table 3. Hinterland geology and geomorphology of SPS locations (gaps indicate not recorded).

\begin{tabular}{|c|c|c|c|c|c|c|c|}
\hline Location & $\begin{array}{l}\text { Shore } \\
\text { platform }\end{array}$ & Cliff & $\begin{array}{l}\text { Storm swash } \\
\text { terrace }\end{array}$ & Dunes & Peat bog & Tufa & Urbanised \\
\hline Cape Point, SA & $\mathrm{Y}$ & $\mathrm{Y}$ & $\mathrm{N}$ & $\mathrm{N}$ & $\mathrm{n} / \mathrm{r}$ & $\mathrm{Y}$ & $\mathrm{N}$ \\
\hline${ }^{1}$ Storms River & $\mathrm{Y}$ & $\mathrm{n} / \mathrm{r}$ & $\mathrm{n} / \mathrm{r}$ & $\mathrm{n} / \mathrm{r}$ & $\mathrm{n} / \mathrm{r}$ & & $\mathrm{N}$ \\
\hline${ }^{1}$ Oyster Bay & $\mathrm{Y}$ & $\mathrm{N}$ & $\mathrm{n} / \mathrm{r}$ & $\mathrm{Y}$ & $\mathrm{n} / \mathrm{r}$ & & Partly \\
\hline${ }^{1}$ Cape St Francis & $\mathrm{Y}$ & $\mathrm{N}$ & $\mathrm{n} / \mathrm{r}$ & $\mathrm{Y}$ & $\mathrm{n} / \mathrm{r}$ & & $\mathrm{Y}$ \\
\hline${ }^{1}$ Seaview & $\mathrm{Y}$ & $\mathrm{N}$ & $\mathrm{n} / \mathrm{r}$ & $\mathrm{Y}$ & $\mathrm{n} / \mathrm{r}$ & & $\mathrm{Y}$ \\
\hline${ }^{1}$ Skoenmakerskop & $\mathrm{Y}$ & $\mathrm{N}$ & $\mathrm{n} / \mathrm{r}$ & $\mathrm{Y}$ & $\mathrm{n} / \mathrm{r}$ & & $\mathrm{N}$ \\
\hline${ }^{1}$ Cape Recife & $\mathrm{Y}$ & $\mathrm{N}$ & $\mathrm{n} / \mathrm{r}$ & $\mathrm{Y}$ & $\mathrm{n} / \mathrm{r}$ & & $\mathrm{N}$ \\
\hline${ }^{2}$ Cape Morgan & $\mathrm{Y}$ & $\mathrm{Y}$ & $\mathrm{Y}$ & $\mathrm{Y}$ & $\mathrm{Y}$ & & $\mathrm{N}$ \\
\hline Luphatana & $\mathrm{Y}$ & $\mathrm{N}$ & $\mathrm{Y}$ & $\mathrm{Y}$ & $\mathrm{Y}$ & & $\mathrm{N}$ \\
\hline Mtentu & $\mathrm{Y}$ & $\mathrm{N}$ & $\mathrm{Y}$ & $\mathrm{Y}$ & $\mathrm{Y}$ & & $\mathrm{N}$ \\
\hline Port Edward & $\mathrm{Y}$ & $\mathrm{N}$ & $\mathrm{Y}$ & $\mathrm{Y}$ & $\mathrm{Y}$ & & $\mathrm{N}$ \\
\hline Ballito & $\mathrm{Y}$ & Minor & $\mathrm{Y}$ & $\mathrm{N}$ & $\mathrm{Y}$ & & $\mathrm{Y}$ \\
\hline Tinley Manor & $\mathrm{Y}$ & Minor & $\mathrm{Y}$ & $\mathrm{N}$ & $\mathrm{Y}$ & & $\mathrm{Y}$ \\
\hline Richards Bay & $\mathrm{N}$ & $\mathrm{Y}$ & $\mathrm{N}$ & $\mathrm{Y}$ & $\mathrm{N}$ & & $\mathrm{N}$ \\
\hline Tofo, Mozambique & $\mathrm{Y}$ & $\mathrm{Y}$ & $\mathrm{N}$ & $\mathrm{Y}$ & $\mathrm{N}$ & & $\mathrm{Y}$ \\
\hline${ }^{3}$ Giant's Causeway, N. Ireland & $\mathrm{Y}$ & $\mathrm{Y}$ & $\mathrm{Y}$ & $\mathrm{N}$ & $\mathrm{N}$ & & $\begin{array}{l}\text { Some } \\
\text { infrastructure }\end{array}$ \\
\hline St John's Point, N. Ireland & $\mathrm{Y}$ & $\mathrm{Y}$ & $\mathrm{n} / \mathrm{r}$ & $\mathrm{n} / \mathrm{r}$ & $\mathrm{N}$ & & $\mathrm{N}$ \\
\hline $\begin{array}{l}\text { Luskentyre Bay (S) } \\
\text { Harris, UK }\end{array}$ & $\mathrm{Y}$ & $\mathrm{Y}$ & $\mathrm{N}$ & $\mathrm{N}$ & $\mathrm{Y}$ & & $\mathrm{N}$ \\
\hline $\begin{array}{l}\text { Luskentyre Bay (N) } \\
\text { Harris, UK }\end{array}$ & $\mathrm{Y}$ & $\mathrm{N}$ & $\mathrm{N}$ & $\mathrm{N}$ & $\mathrm{Y}$ & & $\mathrm{N}$ \\
\hline $\begin{array}{l}\text { Northton } \\
\text { Harris, UK }\end{array}$ & $\mathrm{N}$ & $\mathrm{Y}$ & $\mathrm{N}$ & $\mathrm{N}$ & $\mathrm{Y}$ & & $\mathrm{N}$ \\
\hline${ }^{4}$ Kuwait Bay, Kuwait & $\mathrm{Y}$ & $\mathrm{N}$ & $\mathrm{n} / \mathrm{r}$ & $\mathrm{Y}$ & $\mathrm{N}$ & & $\mathrm{N}$ \\
\hline${ }^{5}$ N. Sea, Netherlands & $\mathrm{N}$ & $\mathrm{N}$ & $\mathrm{n} / \mathrm{r}$ & $\mathrm{n} / \mathrm{r}$ & $\mathrm{N}$ & & $\mathrm{N}$ \\
\hline${ }^{6}$ SW Australia & $\mathrm{Y}$ & $\mathrm{Y}$ & $\mathrm{n} / \mathrm{r}$ & $\mathrm{n} / \mathrm{r}$ & $\mathrm{n} / \mathrm{r}$ & & $\mathrm{N}$ \\
\hline Monkey Mia, W. Australia & $\mathrm{Y}$ & $\mathrm{N}$ & $\mathrm{n} / \mathrm{r}$ & $\mathrm{Y}$ & $\mathrm{N}$ & & $\mathrm{N}$ \\
\hline
\end{tabular}

backed by a retreating coastal cliff made up of the poorly consolidated Port Durnford Beds sediments. Only tufa is present growing on the cliff face but will not be preserved due to ongoing marine action.

\section{SPS hinterland}

Storm swash terrace deposits (McKenna et al., 2012; Dixon et al., 2015) occur at the rear of the Port Edward, Ballito, Tinley Manor, Mtentu, Luphatana, and Cape Morgan shore platforms. These are associated with boulder ridges, boulder beaches, and coastal dunes. Storm swash terrace deposits (McKenna et al., 2012) may partially bury older beach ridges. Boulder beaches are present at the Luskentyre Bay, Harris, Scottish Hebrides (UK), SPS sites but here the hinterland is characterised by peat bog overlying bedrock which projects through at high points (Fig. 6). At Tofo (Mozambique) the tufa is backed by a very extensive (kilometres wide) coastal dune cordon, which is strongly impacted by farming and urbanisation. Several SPS localities have a coastal dune cordon hinterland and some are associated with bogs (Table 3). The hinterland at Giant's Causeway comprises high basalt cliffs (Fig. 6). A model of the SPS facies association is shown in Fig. 7.

\section{Regional and global aspects}

SPS occur in a variety of climatic and oceanographic settings (Table 4) and although no systematic survey of SPS distribution has yet been undertaken, we expect that they are globally widespread. Shore platforms, associated with boulder ridges and boulder beaches, are indicative of high wave activity (Hall et al., 2006; McKenna et al., 2012; Dixon et al., 2015). In the case of the southern African eastern seaboard this is confirmed by modally high wave conditions (Guastella and Rossouw, 2012). Extreme waves, however, exceed modal conditions by several metres. On the southern African eastern seaboard, extreme waves may originate from extratropical low pressure systems, tropical storms/ cyclones (Smith et al., 2010), and tsunamis can also not be ruled out. 
Table 4. Tectonic and oceanographic aspects of SPS localities. Tidal data from the South African Naval Hydrographic Office and British Admiralty (measured values *; Sea level rise ${ }^{a}$, and Sea surface temperature ${ }^{b}$ ) and satides.co.za (modelled data)(n/g: not gauged).

\begin{tabular}{|c|c|c|c|c|c|c|}
\hline Location & Tectonic & $\begin{array}{l}{ }^{a} \text { SLR } \\
\left(\mathrm{mm} \mathrm{yr}^{-1}\right)\end{array}$ & $\begin{array}{r}{ }^{\mathrm{b}} \mathrm{SST} \\
\text { range }\left({ }^{\circ} \mathrm{C}\right)\end{array}$ & $\begin{array}{r}\text { Tidal } \\
\text { range }(\mathrm{M})\end{array}$ & $\begin{array}{l}\text { Wave } \\
\text { regime }\end{array}$ & $\begin{array}{l}\text { Climate } \\
\text { zone }\end{array}$ \\
\hline Cape Point & Passive & $\begin{array}{l}1.94 \\
\text { (Simon's Town) }\end{array}$ & $8-15$ & $1.83^{*}$ & Very high & Mediterranean \\
\hline${ }^{1}$ Storms River & Passive & $\mathrm{n} / \mathrm{g}$ & $15.5-19.5$ & 2.14 & Very high & Moderate coast \\
\hline${ }^{1}$ Oyster Bay & Passive & $\mathrm{n} / \mathrm{g}$ & $16-18$ & 2.12 & Very high & Moderate coast \\
\hline${ }^{1}$ Cape St Francis & Passive & $\mathrm{n} / \mathrm{g}$ & $16-20.5$ & 2.1 & Very high & Moderate coast \\
\hline${ }^{1}$ Seaview & Passive & $\mathrm{n} / \mathrm{g}$ & $16-20$ & $\mathrm{n} / \mathrm{g}$ & Very high & Moderate coast \\
\hline${ }^{1}$ Skoenmakerskop & Passive & $\mathrm{n} / \mathrm{g}$ & $16-23$ & $\mathrm{n} / \mathrm{g}$ & Very high & Moderate coast \\
\hline${ }^{1}$ Cape Recife & Passive & $2.39(\mathrm{PE})$ & $16-23$ & $1.99^{*}$ & Very high & Subtropical coast \\
\hline 2 Cape Morgan & Passive & $\mathrm{n} / \mathrm{g}$ & $17.5-20.5$ & 1.98 & Very high & Subtropical coast \\
\hline Luphatana & Passive & $\mathrm{n} / \mathrm{g}$ & $19-22.5$ & $\mathrm{n} / \mathrm{g}$ & Very high & Subtropical coast \\
\hline Mtentu & Passive & $\mathrm{n} / \mathrm{g}$ & $19-22.5$ & $\mathrm{n} / \mathrm{g}$ & Very high & Subtropical coast \\
\hline Port Edward & Passive & $\mathrm{n} / \mathrm{g}$ & $19.5-23$ & 2.05 & Very high & Subtropical coast \\
\hline Ballito & Passive & 1.23 (Durban) & $20.5-24.5$ & $2.13 *$ & Very high & Subtropical coast \\
\hline Tinley Manor & Passive & $\mathrm{n} / \mathrm{g}$ & $20.5-24.5$ & $\mathrm{n} / \mathrm{g}$ & Very high & Subtropical coast \\
\hline Richards Bay & Passive & $\mathrm{n} / \mathrm{g}$ & $20-24.5$ & 2.3 & Very high & Subtropical coast \\
\hline Tofo & Passive & $\mathrm{n} / \mathrm{g}$ & $22-29$ & 5.0 & Very high & Tropical coast \\
\hline${ }^{3}$ Giant's Causeway & Epeirogenic & $\begin{array}{l}0.07 \\
\text { (Dublin) }\end{array}$ & $7.9-15.3$ & $\begin{array}{r}2.4^{*} \\
\text { (Port Rush) }\end{array}$ & High & Cool temperate \\
\hline St John's Point & Epeirogenic & $\begin{array}{l}0.07 \\
\text { (Dublin) }\end{array}$ & $7.4-15.4$ & $\begin{array}{r}2.4^{*} \\
\text { (Port Rush) }\end{array}$ & High & Cool temperate \\
\hline Luskentyre Bay (S) & Epeirogenic & $\begin{array}{l}1.92 \\
\text { (Stornoway) }\end{array}$ & & $\begin{array}{r}4.4^{*} \\
\text { (Tarbert) }\end{array}$ & Moderate & Cool temperate \\
\hline Luskentyre Bay (N) & Epeirogenic & $\begin{array}{l}1.92 \\
\text { (Stornoway) }\end{array}$ & & $\begin{array}{r}4.4^{*} \\
\text { (Tarbert) }\end{array}$ & Moderate & Cool temperate \\
\hline Northton & Epeirogenic & $\begin{array}{l}1.92 \\
\text { (Stornoway) }\end{array}$ & & $\begin{array}{r}4.4^{*} \\
\text { (Tarbert) }\end{array}$ & Very high & Cool temperate \\
\hline${ }^{4}$ Kuwait & Epeirogenic & NA & $13.3-32.3$ & $\begin{array}{r}4.3^{*} \\
\text { (Kuwait Bay) }\end{array}$ & Low & Dry desert \\
\hline${ }^{5}$ SW Australia & Passive & $\begin{array}{l}1.54 \\
\text { (Fremantle) }\end{array}$ & & NA & NA & Mediterranean \\
\hline Monkey Mia, W. Australia & Epeirogenic & $\begin{array}{l}2.89 \\
\text { (Carnarvon) }\end{array}$ & & NA & NA & Dry desert \\
\hline${ }^{6}$ N. Sea, Netherlands & Epeirogenic & $\begin{array}{l}1.71-2.53 \\
\text { (Netherlands) }\end{array}$ & & NA & NA & Cool temperate \\
\hline
\end{tabular}

$\mathrm{NA}=$ not available

${ }^{1}$ Perissinotto et al. (2014), ${ }^{2}$ Smith and Uken (2003), ${ }^{3}$ Cooper et al. (2013), ${ }^{4}$ Alshuaibi et al. (2015), ${ }^{5}$ Forbes et al. (2010), ${ }^{6}$ Kremer et al. (2008). Sea surface temperature data obtained from Smit et al. (2013) for South Africa and Alshuaibi et al. (2015) for Kuwait.

A high swell event on 18-20 March 2007 (impacts ranged from Port Elizabeth to Maputo) (Fig. 1), was produced by a cut-off low pressure system. This event produced swells up to $14 \mathrm{~m}$ high $\left(H_{\mathrm{s}}=8.5 \mathrm{~m}\right)$ with run-ups of 7-11 $\mathrm{m}$ (a.m.s.l.). (Smith et al., 2007). A further high swell event between 31 August and the 1st September 2008 impacted the southern and south-east African coast, from Cape Point to Cape Morgan (Fig. 1). This was generated by an extremely deep low pressure system and produced swells of $H_{\mathrm{s}}=10.7 \mathrm{~m}$ (Guastella and Rossouw, 2012) with a 7-8 m run-up at Cape Morgan (Smith et al., 2014).

Field inspection following both the March (2007) and September (2008) high swell events indicated changes to the
Cape Morgan colonies (the other colonies listed in Table 1 were unknown prior to 2007). In the case of both storms, growing and unconsolidated microbial mat and large blocks of tufa were largely removed by wave action, but lithified stromatolites remained on the shore platform. Following the March 2007 event, surface stromatolite growth at Cape Morgan had been largely restored by January 2008.

At Ballito (Fig. 1), sub-fossil peritidal stromatolites that had been buried under coastal reclamation were exposed by erosion during the same 2007 high swell event. This event deposited a boulder beach (boulders $>1 \mathrm{~m}$ diameter) over the dolerite sill shore platform. At one point a thin crust of subfossil stromatolites was observed, which extended landward 
under the boulder beach and storm swash terrace. This shows that SPS can be interbedded with storm deposits. At Cape Morgan, boulders on the boulder beach are often coated by stromatolite growth indicating periods of disaggregation and stability. Several rounded boulders were found with multiple rims of stromatolite, indicating they had experienced several cycles of stability and movement.

At Luphatana an extant SPS colony is located just in front of a boulder ridge which contains $80 \mathrm{t}$ boulders, indicative of extreme waves (date unknown), the parameters of which are as yet unquantified (Fig. 5a). Similarly the St Johns Point and Giant's Causeway stromatolites (Cooper et al., 2013) are both associated with very large boulders. Wave spray deposits have been found at levels of $60 \mathrm{~m}$ (a.m.s.l.) at Cape Morgan, South Africa (Smith et al., 2014), whilst at Aird Uig (Harris, Scotland) wave scouring has taken place on a cliff top at a height of 20-30 m OD (Hall et al., 2006), proving that SPS can withstand the present extremes in wave climate.

The Irish and Scottish coasts are known for strong wave action (Hall et al., 2006; O'Brien et al., 2013) as the 20132014 storm season proved (Wadey et al., 2015). Both Giant's Causeway (on the west coast) and Luskentyre Bay are afforded some protection, but the boulder storm beaches at both localities (Table 2) have shown themselves to be vulnerable to wave attack.

It must be restated that this sample is far from complete, representing only coastlines that have been investigated. From Table 4, however, the following about extant SPS can be noted:

- SPS have been recorded in passive plate margins and epeirogenic settings.

- They occur from microtidal to macrotidal environments.

- Colonies have been noted in regions with sea level rises varying from 0.07 to $2.89 \mathrm{~mm} \mathrm{yr}^{-1}$.

- SPS form in coastal areas with sea surface temperatures varying from 7.4 to $32.3^{\circ}$.

- Colonies have been found in cool temperate to dry desert regions.

- SPS colonies are found in areas with varying high wave regimes - all characterised by boulders.

\section{Discussion}

SPS grow in shore platform depressions on high-energy coasts, such as shallow rock pools (Smith et al., 2011; Perissinotto et al., 2014; Rishworth et al., 2016), potholes, and SPS dammed barrage pools (Forbes et al., 2010; Perissinotto et al., 2014). SPS comprise thin micritic crusts, with only rare examples of trapped and bound stromatolite varieties being associated. Not all localities show the complete tripartite stromatolite morphology (Fig. 4a). The pustular variety may be absent but the subaqueous laminar and columnar and the colloform variety are ubiquitous. Where vertical surfaces are present tufa grows.

Any SPS model must take into account that they form at the interface of freshwater seeps and high energy rocky peritidal zones (Smith et al., 2011; Perissinotto et al., 2014). The SPS are calcium carbonate mineralised due to the high pH regime (Smith et al., 2011) and grow on older siliceous rocks (Tofo may be an exception but the base is not visible) within a siliciclastic contemporary setting. Mud and sand pass through this system but are not deposited in significant amounts. Microbialites are ubiquitous in the peritidal setting but only become stromatolites if a carbonate rich groundwater plume is present (Smith et al., 2011; Rishworth et al., 2016).

The following points also need to be considered, although they may, or may not, be necessary for SPS growth. Sea level rise is ongoing. SPS possess seasonal to sub-seasonal (due to storm abrasion) laminae (Smith et al., 2005). The lack of climax lamination (Reid et al., 2000), characterised by diatoms (Smith et al., 2005) in the calcified form may be due to storm activity or non-calcification of this lamina type. Warm thermal groundwater may be present indicating a groundwater source. The stromatolites and shore platform contact is an unconformity.

The diversity of shore platform substrates suggests that lithology is not important for SPS growth; however, the competency of the substrate is vital for growth and probably for potential preservation. Tufa deposits and pustular stromatolite deposits are very unlikely to survive transgression or regression as there is no accommodation space. However, SPS in rock pools and barrage pool build-ups can form lenses or layers of stromatolite which could then be overstepped during marine transgression (possibly similar to the multi-metre steps which post-dated the last glacial maximum) and preserved in a future stratigraphy. Marine processes may break up the stromatolites and free stromatolite encrusted boulders from barrage and rock pools, such as is seen at Cape Morgan (Fig. 2a), and transport them as littoral drift for deposition elsewhere as conglomerates. Sea level rise (SLR) is taking place globally, thus SPS deposits could form as part of a global transgressive coastal sequence.

The best opportunity for preservation is provided by rock pools, especially potholes, in competent shore platform rock as this provides accommodation space. SPS growth itself could seal the SPS deposit, especially in flat bedded competent sandstone as at Mtentu and Luphatana (Fig. 5). Thus SPS environments could be preserved as lenses on palaeo-shore platforms. The extant stromatolite regrowth seen at Ballito (Fig. 1) suggests that preservation can take place. An investigation of subaqueous post-last glacial maximum coastlines might resolve this issue. 


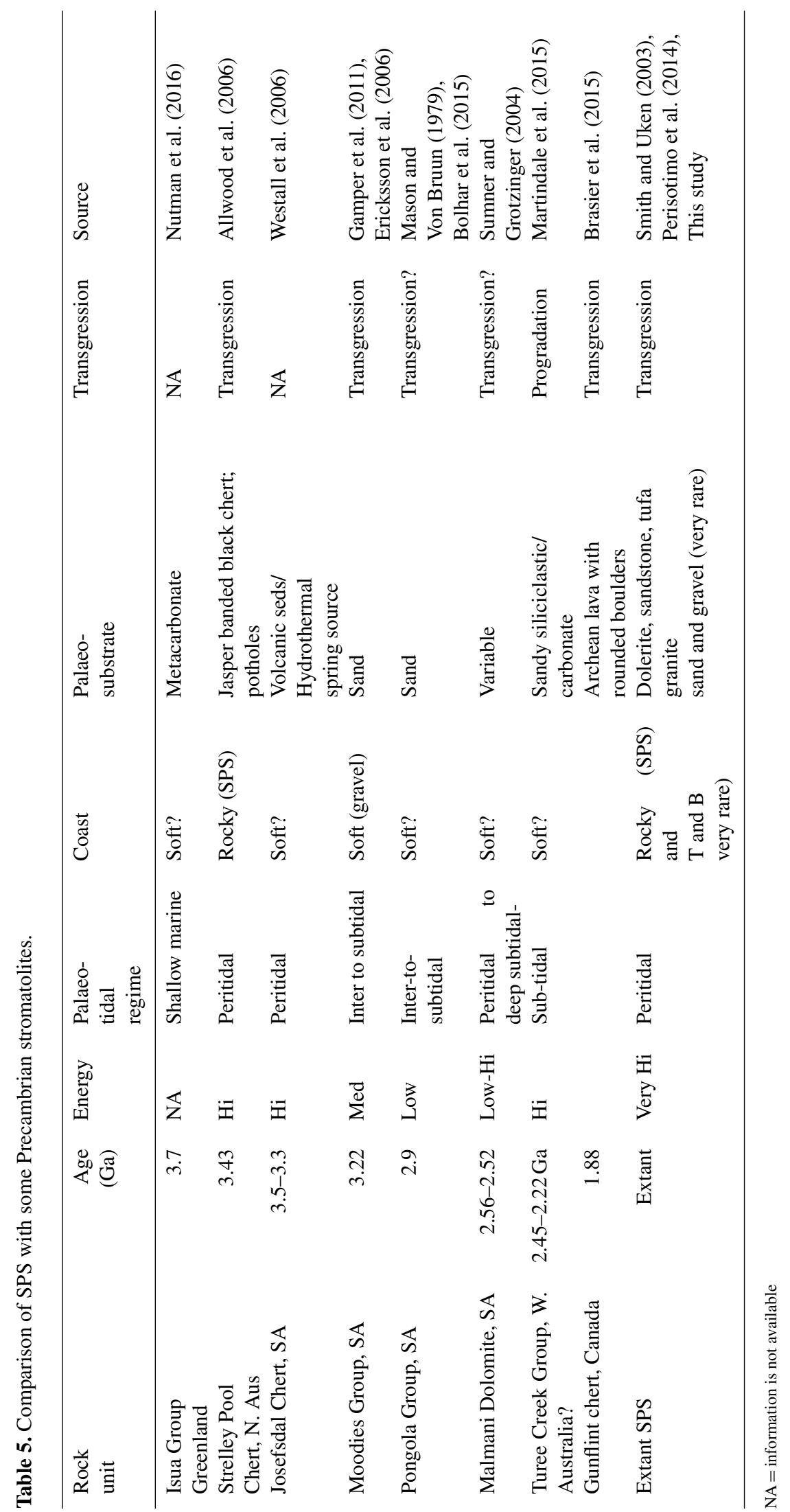




\subsection{Global extant stromatolites}

There are several important differences between the extant SPS described here and other, well known extant stromatolite occurrences. Variations on the Hamelin Pool theme are generally used for artists' conceptions of the Archean; however this instance is unusual as within a hypersaline lagoon (Logan et al., 1964). The Highborne Cay, Bahamas sub-tidal model is characterised by columnar stromatolites within an ooid shoal (Reid et al., 1995; Visscher et al., 1998; Baumgartner et al., 2009). Both Shark Bay and the Bahamian extant stromatolite settings contain stromatolites produced by trapping and binding within a soft coastline. These may leave traces such as microbially induced sedimentary structures (MISS) (Noffke and Awramik, 2013) but are unlikely to be preserved in the long term. Kremer et al. (2008) found calcium carbonate being precipitated within annual Cyanobacteria mats at beaches on the Dutch North Sea, but again these were of the trapped and bound variety, as opposed to mineral precipitation. The Kuwait Bay examples (Alshuaibi et al., 2015), however, are of the mineral precipitation variety; these are developed on beach rock and could conceivably be preserved.

\subsection{Precambrian stromatolites}

Precambrian stromatolites are commonly found to have developed in transgressive settings on varying substrate types (Table 5). Erosion surfaces are common within them (Van Kranendonke, 2011; Nutman et al., 2016) as is the case with SPS. In the case of Strelley Pool (Australia), stromatolites initially formed on a rocky shore platform (Allwood et al., 2006), which compares well with SPS (Tables 1 and 2). Allwood et al. (2006) base this interpretation on the following:

1. Wide and discontinuous distribution of boulders with a rounded clast-supported fabric.

2. Correlation between clast and substrate, on an unconformity.

3. Substrate-dependent lateral transition from clustered and isolated large boulders on a shore platform to embayment beach conglomerates type.

4. The presence of palaeo-cliffs, fissures, and cavities in the substrate.

5. Soft mud intraclasts and desiccation cracks associated with local mudstone substrate.

The extant SPS facies association demonstrates all the points made by Allwood et al. (2006) concerning the Strelley Pool stromatolites (Tables 1 and 2); the stromatolite morphological scale of the two is also similar. Although the SPS horizontal exposures vary from 10 to $100 \mathrm{~s}$ of metres, they are time equivalents and, if conditions where right, could develop into beds stretching for 10 or $100 \mathrm{~s}$ of kilometres. The presence of "stromatolites" on vertical surfaces at Strelley Pool is interesting as this suggests that they were associated with tufa. This, in turn, shows that tufa can be preserved despite the perceived lack of accommodation space. The $1.88 \mathrm{Ga}$ Gunflint Chert is based on a weathered Archean lava, characterised by rounded lava boulders (Brasier et al., 2015) and may also be a palaeo-SPS occurrence.

In contrast to SPS most Precambrian stromatolites apparently formed on soft coastlines (Table 5). Perhaps the Precambrian marine climate was markedly less aggressive than at present or stromatolites were simply preserved in low energy embayments such as Kuwait Bay (Alshuaibi et al., 2015) or Luskentyre Bay.

The presence of tufa within the SPS facies association and its similarity to that of the $3.4 \mathrm{Ga}$ Strelley Pool stromatolites strongly hints that microbial life existed in Archean terrestrial settings. It is quite reasonable to assume that tufa was present landward of Archean stromatolite settings, but was not preserved.

\subsection{SPS as a modern Precambrian analogue}

It has been suggested that no adequate marine extant stromatolite analogue exists for Precambrian marine mineral precipitated stromatolites, as most modern marine extant stromatolites are of the trapped and bound variety (Awramik and Grey, 2005). However, the mineral precipitated SPS deposits fill this gap. Most Precambrian stromatolites formed in a transgressive setting, similar to the SPS (Table 5). The peritidal stromatolite setting is a common theme for Precambrian stromatolites; although intertidal and subtidal components are also present (Table 5). The SPS setting shows only a stunted intertidal and no subtidal component. Microbialite develops in the crack between terrestrial and marine influence where metazoans are reduced by the extreme nature of this setting, and thus competition for space is reduced. If the groundwater chemistry is suitable, SPS form. It is easy to imagine how the SPS environment would unfold if metazoan activity was reduced or not present, as was the case in the Precambrian; this would allow large subtidal stromatolites, such as those in the Malmani Dolomite (Sumner and Grotzinger, 2004) (Table 5) to develop. Similarly it is very likely that tufa existed in the terrestrial environment, but has not been preserved (or recognised). The SPS model strongly suggests the occurrence of terrestrial prokaryotes during the Archean. Extant SPS are growing during a mild transgression, thus their preservability at present is probably low. However, should SLR accelerate in the future, it is possible that this environment could be overstepped and preserved as rock pool and pothole fills. The lower colloform and laminar stromatolite variety are more likely to be preserved and the tufa least likely or not at all. 


\subsection{Extraterrestrial implications}

Phosphorous on Mars is more common than on Earth (Greenwood et al., 2007) so it is possible that simple Martian life may have been present. If this was the case, and the water chemistry was suitable, then stromatolites could have formed. Marine and lacustrine flooding surfaces on Mars should be consequently be investigated. Palaeo-shore platforms, especially if associated with megaclast fields or ridges, should be targets for investigation. Although no shore platforms have been reported (Banfield et al., 2015) as yet, the terrain at Chryse Planitia and Arabia Terra, which border the postulated Vastitas Borealis Ocean (Wilson et al., 2016; Rodriguez at al., 2016), could be shore platform candidates. Recently Ruff and Farmer (2016) suggested that structures in the Ma'Adim terraces within the Gusev Crater are siliceous stromatolites. These terraces may have been formed by wave action in the Gusev Palaeolake or at the margin of the Vastitas Borealis Ocean and may be an extraterrestrial palaeo-SPS environment.

\section{Conclusions}

Extant SPS are present on high energy rocky coasts, on passive margins, and in epeirogenic settings; however this may be a function of sampling. They are associated with well-indurated shore platforms, boulder ridges, and boulder beaches. The hinterland is frequently boggy or marshy. SPS appear to be unrelated to climate and tidal regime, but they may be better developed in warmer climates but the sample size is currently too small to confirm this. If vertical surfaces are present on the shore platform, tufa forms. In shallow shore platform pools SPS develop. There is a gradation from SPS to tufa. SPS develop within transgressive settings, as was the case with many Precambrian stromatolites. The preservability of these micrite stromatolites is probably low, but may improve with stromatolite cementation to competent substrate rock. Contemporary rocky and Quaternary coastlines should be investigated globally for the SPS environment. The SPS setting is a valid analogue for the Archean Strelley Pool stromatolite and possibly the base of the Gunflint stromatolite occurrence; however, most Precambrian stromatolites appear to have formed on soft coastlines. The association with trapped and bound stromatolites and the Luskentyre Bay environment (shore platform and tidal flat) hints at a possible SPS soft coastline link. Finally, shore platform settings should be targets in the search for Martian stromatolites.

Data availability. All the data used are presented in tables and images of this article.
Competing interests. The authors declare that they have no conflict of interest.

Acknowledgements. We would like to acknowledge the support of the universities of KwaZulu-Natal, Durban South Africa and Ulster, Northern Ireland. We also acknowledge the National Research Foundation (grant no. 91089) for support. In addition we also acknowledge the assistance of AJ Smit and Robert Schlegel, University of the Western Cape, for supplying SST data. Finally we would like to thank the three anonymous reviewers, who helped improve this paper.

Edited by: Tina Treude

Reviewed by: three anonymous referees

\section{References}

Allwood, A. C., Walter, M. R., Kamber, B. S., Marshall, C. P., and Burch, I. W.: Stromatolite reef from the Early Archean era of Australia, Nature, 441, 714-718, 2006.

Alshuaibi, A. A., Khalaf, F. I., and Zamel, A. A.: Calcareous thrombolitic crust on Late Quaternary beachrocks in Kuwait, Arabian Gulf, Arab. J. Geosci., 8, 9721-9732, https://doi.org/10.1007/s12517-015-1869-5, 2015.

Awramik, S. M. and Marguilis, L.: Developments in Sedimentology, Stomatolites, edited by: Walter, M., Amsterdam, Elsevier, Vol. 20, 790 pp., 1976.

Awramik, S. M. and Grey, K.: Stromatolites: Biogenicity, Biosignatures, and Bioconfusion, in: Astrobiology and Planetary Missions, edited by: Hoover, R. B., Levin, G. V., Rozanov, A. Y., and Gladstone, G. R., Proc. of SPIE 5906, 59060P, 2005.

Banfield, D., Donelan, D., and Cavaleri, L.: Winds, waves and shorelines from ancient Martian seas, Icarus, 250, 368-383, 2015.

Baumgartner, L. K., Spear, J. R., Buckley, D. H., Pace, N. R., Reid, R. P., Dupraz, C., and Visscher, P. T.: Microbial diversity in modern marine stromatolites, Highborne Cay, Bahamas, Environ. Microbiol., 11, 2710-2719, 2009.

Berelson, W. M., Corsetti, F. A., Pepe-Ranney, C., Hammonde, D. E., Beaumont, T. W., and Spear, J. R.: Hot spring siliceous stromatolites from Yellowstone National Park: assessing growth rate and laminae formation, Geobiology, 9, 411-424, 2011.

Bolhar, R., Hofmann, A., Siahi, M., Feng, Y., and Delvigne, C.: A trace element and $\mathrm{Pb}$ isotopic investigation into the provenance and deposition of stromatolitic carbonates, ironstones and associated shales of the $\sim 3.0$ Ga Pongola Supergroup, Kaapvaal Craton, Geochim. Cosmochim. Ac., 158, 57-78, 2015.

Brasier, M. D., Antcliffe, J., Saunders, M., and Wacey, D.: Changing the picture of Earth's earliest fossils $(3.5-1.9 \mathrm{Ga})$ with new approaches and new discoveries, P. Natl. Acad. Sci. USA, 112, 4859-4864, 2015.

Burne, R. V. and Moore, L. S.: Microbialites: organosedimentary deposits of benthic microbial communities, Palaios, 2, 241-254, 1987.

Campbell, K. A., Guido, D. M., Gautret, P., Foucher, F., Ramboz, C., and Westall, F.: Geyserite in Hot-Spring Siliceous Sinter: Window on Earth's Hottest Terrestrial (Pa- 
leo)environment and its Extreme Life, Earth Sci. Rev., 148, 44-6, https://doi.org/10.1016/j.earscirev.2015.05.009, 2015.

Cooper, J. A. G., Smith, A. M., and Arnscheidt, J.: Contemporary stromatolite formation in high intertidal rock pools, Giant's Causeway, Northern Ireland: preliminary observations, J. Coastal Res., 65, 1675-1680, 2013.

DeLeon-Rodriguez, N., Lathem, T. L., Rodriguez, L. M., Barazesh, J. M., Anderson, B. E., Beyersdorf, A. J., Ziemba, L.D., Bergin, M., Nenes, A., and Konstantinidis, K. T.: Microbiome of the upper troposphere: Species composition and prevalence, effects of tropical storms, and atmospheric implications, P. Natl. Acad. Sci. USA, 110, 2575-2580, 2012.

Dixon, S., Green, A. N., and Cooper, J. A. G.: Storm swash deposition on an embayed coastline facies, formative mechanisms, and preservation, J. Sediment. Res., 85, 1155-1165, 2015.

Edwards, M. J. K, Anderson, C. R., Perissinotto, R., and Rishworth, G. M.: Macro- and meso-fabric structures of peritidal tufa stromatolites along the Eastern Cape coast of South Africa, Sediment. Geol., 359, 62-75, 2017.

Forbes, M., Vogwill, R., and Onton, K. A.: Characterization of the coastal tufa deposits of south-west Western Australia, Sediment. Geol., 232, 52-65. https://doi.org/10.1016/j.sedgeo.2010.09.009, 2010.

Gamper, A., Heubeck, C., Demsked, D., and Hoehse, M.: Composition and microfacies of Archean microbial mats (Moodies Group, 3.22 Ga, South Africa), Microbial Mats in Siliciclastic Depositional Systems Through Time SEPM Special Publication No. 101, Copyright_2011 SEPM (Society for Sedimentary Geology), ISBN 978-1-56576-314-2, 65-74, 2011.

Greenwood, J. P., Blake, R. E., Barron, V., and Torrent, J.: Phosphorus geochemistry of Mars: evidence for an early acidic hydrosphere, Seventh International Conference on Mars, 913 July 2007, Pasadena, California, 2007.

Guastella, L. A. and Rossouw, M.: What will be the impact of increasing frequency and intensity of coastal storms along the South African coast?, Reef J., 2, 129-139, 2012.

Hall, A. M., Hansom, J. D., Williams, D. M., and Jarvis, J.: Distribution, geomorphology and lithofacies of cliff-top storm deposits: Examples from the high-energy coasts of Scotland and Ireland, Marine Geol., 232, 131-155, 2006.

Jones, B., Renault, R. W., and Rosen, M. R.: Stromatolites Forming in Acidic Hot-Spring Waters, North Island, New Zealand, Palaios, 15, 450-475, 2000

Kremer, B., Kazmierczak, J., and Stal, L. J.: Calcium carbonate precipitation in Cyanobacterial mats from sandy tidal flats of the North Sea, Geobiology, 6, 46-56, 2008.

Logan, B. W., Rezak, R., and Ginsberg, R. N.: Classification and environmental significance of algal stromatolites, J. Geol., 72, 68-83, 1964.

Martin, H. and Wilczewski, I.: Algen-stromatolithen aus der Etoscha-Pfanne, Sudwest-Afrikas, Neues Jb. Geol. Palaont. Mh., 12, 720-726, 1972.

Martindale, R. C., Strauss, J. V., Sperling, E. A., Johnson, J. E., Van Kranendonke, M. J., Flannery, D., French, K., Lepoti, K., Mazumder, R., Rice, M. S., Schrag, D. P., Summons, R., Walter, M., Abelson, J., and Knoll, A. H.: Sedimentology, chemostratigraphy, and stromatolites of lower Paleoproterozoic carbonates, Turee Creek Group, Western Australia, Precambrian Res., 266, 194-211, 2015.
Mason, T. R. and von Brunn, V.: 3.0 G.y. old stromatolites from South Africa, Nature, 266, 47-49, 1977.

McKenna, J., Cooper, J. A. G., and Jackson, W. T.: Storm Swash Terraces: A Previously Overlooked Element of the Cliff-Shore Platform, Syst. J. Sediment. Res., 82, 260-269, 2012.

Mountain, E. D.: Tufa-lined basins in coastal platforms (East London Region, Cape of Good Hope), South Afr. J. Sci., 33, 242 247, 1937.

Noffke, N. and Awramik, S.: Stromatolites and MISS: differences between relatives, GSA Today, 23, 5-9, 2013.

Nutman, A. P., Bennett, V. C., Friend, C. L., Van Kranendonke, M. J., and Chivas, A. R.: Rapid emergence of life shown by discovery of 3,700-million-year-old microbial structures, Nature, 537, 535-537, https://doi.org/10.1038/nature19355, 2016.

O'Brien, L., Dudley, J. M., and Dias, F.: Extreme wave events in Ireland: 14680 BP-2012, Nat. Hazards Earth Syst. Sci., 13, 625648, https://doi.org/10.5194/nhess-13-625-2013, 2013.

Perissinotto, R., Bornman, T. G., Steyn, P., Miranda, N. A. F., Dorrington, R. A., Matcher, G. F., Strydom, N., and Peer, N.: Tufa stromatolite ecosystems on the South African south coast, South Afr. J. Sci., 110, 1-8, 2014.

Reid, R. P. and Brown, K. M.: Intertidal stromatolites in a fringing Holocene reef complex in the Bahamas, Geology, 19, 15-18, 1991.

Reid, R. P., Macintyre, I. G., Steneck, R. S., Browne, K. M., and Miller, T. E.: Stromatolites in the Exuma Cays, Bahamas: Uncommonly common, Facies, 33, 1-18, 1995.

Reid, R. P., Visscher, P. T, Decho, A. W, Stolz, J. F., Beboutk, B. M., Dupraz, C., Macintyre, I. J., Paerl, H. W., Pinckney, J. L., Prufert-Beboutk, L., Steppe, T. F., and DesMaraisk, D. J.: The role of microbes in accretion, lamination and early lithification of modern marine stromatolites, Nature, 406, 989-992, 2000.

Reid, R. P., Foster, J. S., Radtke, G., and Golubic, S.: Modern Marine Stromatolites of Little Darby Island, Exuma Archipelago, Bahamas, in: Advances in Stromatolite Geobiology, edited by: Reitner, J., Quéric, N., and Arp, G., Lecture Notes in Earth Sciences 131, https://doi.org/10.1007/978-3-642-104152_4, Springer-Verlag, Berlin Heidelberg, 2011.

Rishworth, G. M., Perissinotto, R., Miranda, N. A. F., Bornman, T. G., and Steyn, P.: Phytoplankton community dynamics within peritidal pools associated with living stromatolites at the freshwater-marine interface, Aquat. Sci., 79, 1-12, https://doi.org/10.1007/s00027-016-0502-3, 2016.

Rishworth, G. M., Perissinotto, R., Bird, M. S., Strydom, N. A., Nasreen Peer, Miranda, A. F., and Raw, J. L.: Non-reliance of Metazoans on stromatolite-forming microbial mats as a food resource, Sci. Rep., 7, 42614 https://doi.org/10.1038/srep42614, 2017.

Rodriguez, J. A. P., Fairén, A. G., Linares, R., Zarroca, M., Platz, T., Komatsu, G., Karge, J. S., Gulick, V., Jianguo, Y., Higuchi, K., Miyamoto, H., Baker, V. R., and Glines, N.: Tsunami waves extensively resurfaced the shorelines of an early Martian ocean, 47th Lunar and Planetary Science Conference, 2016, 1680 pp., 2016.

Ruff, S. W. and Farmer, J. D.: Silica deposits on Mars with features resembling hot spring biosignatures at El Tatio in Chile, Nat. Commun., 7, 13554, https://doi.org/10.1038/ncomms13554, 2016. 
Sankaran, A. V.: Entombed bacteria deep inside the Earth, Curr. Sci., 73, 495-97, 1997.

Smit, A. J., Roberts, M., Anderson, R. J., Dufois, F., Dudley, S. F. J., Bornman, T. G., Olbers, J., and Bolton, J. J.: A Coastal Seawater Temperature Dataset for Biogeographical Studies: Large Biases between in situ and Remotely-Sensed Data Sets around the Coast of South Africa, PLoS ONE, 8, e81944, https://doi.org/10.1371/journal.pone.0081944, 2013.

Smith, A. M. and Uken, R.: Living marine stromatolites at Kei River mouth, South Afr. J. Sci., 99, 200, 2003.

Smith, A. M., Uken, R., and Thackeray, Z.: Cape Morgan peritidal stromatolites: the origin of lamination, South Afr. J. Sci., 101, 107-108, 2005.

Smith, A. M., Guastella, L. A., Bundy, S. C., and Mather, A. A.: Combined marine storm and Saros spring-high tide erosion event, March 19-20, 2007: a preliminary assessment, South Afr. J. Sci., 103, 274-276, 2007.

Smith, A. M., Mather, A. A., Bundy, S. C., Cooper, J. A. G., Guastella, L. A., Ramsay, P. J., and Theron, A.: Contrasting styles of swell-driven coastal erosion: examples from KwaZuluNatal, South Africa, Geological Magazine, 147, 940-953, 2010.

Smith, A. M., Andrews, J. E., Uken, R., Thackeray, Z., Perissinotto, R., Leuci, R., and Marca-Bell, A.: Rock pool tufa stromatolites on a modern South African wave-cut platform: partial analogues for Archean stromatolites?, Terra Nova, 23, 375-381, 2011.

Smith, A. M., Green, A. N., Cooper, J. A. G., Dixon, S., Pretorius, L., Wiles, E., and Guastella, L. A.: Cliff-top storm deposits (5563 m a.m.s.1.) from Morgans Bay, South Africa, in: Proceedings 13th International Coastal Symposium (Durban, South Africa), edited by: Green, A. N. and Cooper, J. A. G., J. Coastal Res., 70, 349-353, 2014
Sumner, D. Y. and Grotzinger, J. P.: Implications for NeoArchean ocean chemistry from primary carbonate mineralogy of the Campbellrand-Malmani Platform, South Africa, Sedimentology, 51, 1-27, 2004.

Van Kranendonke, M. J.: Morphology as an Indictor of Biogenicity for 3.5-3.2 Ga Fossil Stromatolites from the Pilbara Craton, Western Australia, Advances in Stromatolite Geobiology, Lecture Notes Earth Sci., 131, online first, https://doi.org/10.1007/978-3-642-10415-2_32, 2011.

Visscher, P. T., Reid, R. P., Bebout, B. M., Hoeft, S. E., Macintyre, I. G., and Thompson Jr., J. A.: Formation of lithified micritic laminae in modern marine stromatolites (Bahamas): the role of sulfur cycling, Am. Mineral., 83, 1482-1494, 1998.

Wadey, M. P., Brown, J. M., Haigh, I. D., Dolphin, T., and Wisse, P.: Assessment and comparison of extreme sea levels and waves during the 2013/14 storm season in two UK coastal regions, Nat. Hazards Earth Syst. Sci., 15, 2209-2225, https://doi.org/10.5194/nhess-15-2209-2015, 2015.

Westall, F., de Ronde, C. E. G., Southam, G., Grassineau, N., Colas, M., Cockell, C., and Lammer, H.: Implications of a 3.4723.333 Gyr-old subaerial microbial mat from the Barberton greenstone belt, South Africa for the UV environmental conditions on the early Earth, Philos. T. Roy. Soc. B, 361, 1857-1875, 2006.

Wilson, S. A., Howard, A. D., Moore, J. M., and Grant, J. A.: A cold-wet middle-latitude environment on Mars during the Hesperian Amazonian transition: Evidence from northern Arabia valleys and paleolakes, J. Geophys. Res. Planet., 121, 1667-1694, https://doi.org/10.1002/2016JE005052, 2016. 